\title{
Terapia ocupacional y rehabilitación post quirúrgica en pacientes con cáncer de mamas: Manejo de los síntomas físicos y emocionales \\ Erna Navarrete Salas
}

Resumen

La intervención de Terapia Ocupacional aminora la discapacidad en pacientes operadas de cáncer de mama, facilitando su recuperación e independencia funcional. El espectro de disfunciones que presentan estas pacientes es amplio, e incluye dificultades físicas, psicológicas, emocionales y sociales. El Terapeuta Ocupacional integra un equipo multidisciplinario de rehabilitación, dentro del cual participa con un enfoque clínico centrado en las pacientes y en el manejo de sus disfunciones, capacitándolas de manera individual para adaptarse a sus limitaciones.

\begin{abstract}
Occupational Therapy intervention minimizes disability in patients with breath cancer and surgical treatment, facilitates recovery and functional independence. The large range of dysfunction by patients with breast cancer includes physical, psychological, emotional and social difficulties. The Occupational therapist integrates a multiprofessional rehabilitation team, with a client-centered clinic approach, problemsolving for dysfunction management, and enables patients to adapt themselves to disabilities.
\end{abstract}

